\title{
URGENSI KEPEMIMPINAN PROFETIK DALAM MEWUJUDKAN MASYARAKAT MADANI
}

\author{
Syahdara Anisa Makruf \\ Universitas Islam Indonesia, Yogyakarta \\ Jl. Kaliurang KM 14,5 Yogyakarta \\ Email:133100508@uii.ac.id \\ DOI: 10.29313 /tjpi.v6i2.3169
}

Accepted: October 31th, 2017. Approved: January 18th, 2017. Published: January 18th, 2017

\begin{abstract}
Civil society is terminology that adopted from medina city. This terminology describes the condition of society which fair, prosperous, peaceful. These are principles of human rights which implicated well. Although this terminology is difficult to find it in real condition. Because of leadership model is not referring to prophetic leadership. Though civil society only will be applied to prophetic leadership. Collecting data mainly by library research and employing content analysis, this qualitative research found that civil society and prophetic leadership have the same content. Prophetic leadership based on truths, responsibility, communication, and intelligent. Only with this model civil society can be realized.
\end{abstract}

Keywords: Civil Society, Prophetic Leadership, Human Rights.

ABSTRAK

Masyarakat madani merupakan istilah yang diambil dari kata kota Madinah. Istilah yang menggambarkan kondisi masyarakat yang adil, makmur dan damai. Prinsip-prinsip dasar HAM dijalankan dengan baik. Hanya saja istilah tersebut selama ini sulit untuk ditemukan dalam implikasi nyata. Hal ini disebabkan karena model kepemimpinan tidak didasarkan pada kepemimpinan nabi. Padabal konsep masyarakat madani hanya akan bisa terwujud dengan pendekatan kepemimpinan profetik. Dengan mengumpulkan data melalui studi pustaka kemudian melakukan content analysis, riset bercorak kualitatf ini menemukan bahwa masyarakat madani dan kepemimpinan profetik memiliki corak yang sama. Kepemimpan profetik sendiri didasarkan pada nilai shiddiq, amanah, thabligh dan fathonah. Hanya dengan ini istilah masyarakat madani dapat diwujudkan.

Kata Kunci: Masyarakat Madani, Kepemimpinan Profetik, Hak Asasi Manusia. 


\section{PENDAHULUAN}

Agus Widjojo dalam tulisan (Yazid, 2010) pernah memaparkan bahwa masyarakat madani ialah mereka yang memiliki kemandirian, jiwa toleransi, mau dan selalu berusaha untuk menolong orang lain, serta aktivitasnya tetap didasarkan pada norma dan etika yang disepakati bersama. Format masyarakat madani menjadi dambaan setiap masyarakat dan bahkan para negarawan. Sebab ada nilai-nilai luhur yang dijadikan sebagai rujukan, dan terimplikasikan dengan baik dalam kehidupan sehari-hari.

Disisi lain Azzumardi Azra (2004) dalam bukunya "Menuju Masyarakat Madani" menjelaskan masyarakat madani adalah masyarakat yang patuh terhadap hukum yang telah ditetapkan, memiliki jiwa yang berkeadilan, dan selalu memberikan masukan dan kritik pada pemerintah untuk mewujudkan sistem check and balance antara negara dengan masyarakat. Artinya ada sistem keadilan yang terbentuk dalam masyarakat, namun semuanya tidak bersifat satu arah. Masyarakat dan negara saling bahu membahu dalam mewujudkan masyarakat yang sejahtera.

Dari pemaparan beberapa tokoh tersebut, terlihat bahwa masyarakat madani merupakan tujuan dari setiap negara dan warga negara. Setiap orang memiliki hak yang sama antara yang satu dengan yang lainnya. Masyarakat mempunyai akses yang sama dalam mendapatkan nilai-nilai keadilan. Di dalam masyarakat madani juga hak-hak dasar warga negara juga terpenuhi.

Keinginan untuk menjadikan masyarakat madani sepertinya sulit tercapai. Hal ini dibuktikan dengan masih banyaknya negara yang berkutat pada masalah pemenuhan kebutuhan dasar. Seperti halnya di Indonesia yang merupakan warga dengan mayoritas umat muslim terbesar di dunia. Mereka masih dipenuhi oleh rasa ketidakadilan, kemiskinan dan kebobrokan akhlak. Disisi lain, di beberapa negara muslim di Timur Tengah masih terjadi perang saudara. Antara satu suku dengan suku yang lain saling berebut posisi untuk menjadi penguasa.

Jika dilihat secara mendalam maka dapat ditemukan bahwa salah satu masalah mendasar dalam mewujudkan masyarakat madani adalah kepemimpinan. Kepemimpinan ini dianggap sebagai pondasi dasar, sebab jika kepemimpinannya baik maka keinginan untuk menciptakan masyarakat madani bisa terpenuhi. Namun jika tidak maka akan sulit tercapai.

Salah satu tawaran konsep kepemimpinan tersebut diutarakan oleh Kuntowijoyo (1991) yaitu konsep kepemimpinan profetik. Implikasi dari konsep kepemimpinan profetik itu sendiri terlihat dari tiga aspek mendasar. Pertama, kepemimpinan profetik diarahkan pada penerapan nilai-nilai humanisasi. Kedua, nilai yang melepaskan manusia dari kebodohan, kemiskinan dan ketertindasan atau disebut liberasi. Ketiga, nilai humanisasi dan liberasi harus diarahkan pada nilai transendensi.

Akan tetapi, tawaran pencapaian masyarakat madani dengan menggunakan konsep kepemimpinan profetik masih diragukan. Hal ini terlihat dari tulisan Ahimsa Putra (2011) yang secara langsung mempertanyakan tentang kempaanan konsep ini secara sistematis. Nilai ketuhanan seringkali dianggap sebagai batu sandungan dalam menempatkan ilmu kepemimpinan profetik dalam nilai-nilai yang dogmatis. Sehingga implikasi dari penerapan ini hanya bisa dilakukan oleh orang-orang tertentu saja.

\section{PEMBAHASAN}

\section{Pengertian Masyarakat Madani}


dipepolerkan oleh Anwar Ibrahim sewaktu menjabat sebagai perdana menteri Malaysia di sebuah seminar pada tahun 1995 di Masjid Istiqlal Jakarta. Pada saat itu, 
Ibrahim mencoba menjelaskan pengertian masyrakat madani sebagai sebuah sistem sosial yang subur dan didasarkan pada prinsip moral yang menjamin kebebasan individual maupun masyarakat. Dalam kutipan pembicaraannya disebutkan: "Yang dimaksud dengan masyarakat madani adalah sistem sosial yang subur yang berlandaskan kepada prinsip moral yang menjamin keseimbangan antara kebebasan perorangan dengan kestabilan masyarakat. Masyarakat mendorong daya usaha serta inisiatif individu baik dari segi pemikiran, seni, pelaksanaan pemerintaban mengikuti undang-undang dan bukan nafsu atau keinginan individu menjadikan keterdugaan atau predictability serta ketulusan atau transparency sistem."

Dalam pandangan yang Fitria dan Sutrisnowati (2013) istilah Madani berasal dari kata dijelaskan bahwa konsep "Madinah" yang merupakan tempat nabi Hijrah setelah melaksanakan dakwah di Mekkah. Dalam pengertian lain, Muhammad Abduh mencoba merasionalisasikan makna madani dengan dua pengertian, yaitu masyarakat kota dan masyrakat beradab.

Sedangkan Jainuri (2000) menyebutkan bahwa pemaknaan masyarakat madani bagi masyarakat Indonesia sangat sulit, disebabkan oleh istilah yang berbau Arab-Islam tapi tidak ada unsur pengalaman di dalamnya. Oleh sebab itu, istilah masyarakat madani tidak bisa ditafsirkan dengan mudah. Meskipun demikian, bukan berarti istilah ini tidak boleh ditafsirkan dengan penggunaan nama kota madinah.

Menurut Suroto (2015) konsep masyarakat madani sendiri berasal dari kata "Mujtama'Al-madani" yang berarti masyarakat sipil atau masyarakat yang berkewarganegaraan. Secara detail dijelaskan bahwa masyarakat madani adalah masyarakat yang lahir dari sejarah pada saat nabi memimpin Madinah.

Dalam pandangan lain (Febriyani, 2007) dengan pendekatan Al-Quran menjelaskan bahwa konsep masyarakat madani tercantum dalam surah Al-Hajj ayat 41 yang artinya:

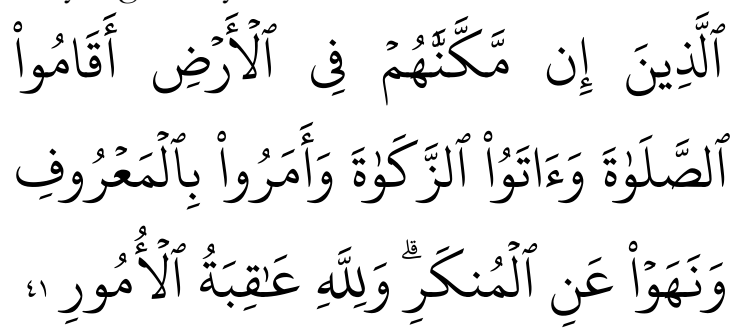

Artinya: (yaitu) orang-orang yang jika Kami teguhkan kedudukan mereka di muka bumi niscaya mereka mendirikan sembahyang, menunaikan zakat, menyuruh berbuat ma'ruf dan mencegah dari perbuatan yang mungkar; dan kepada Allahlah kembali segala urusan

Dan juga terdapat dalam surah $\mathrm{Al}$ Mukminun ayat 52:

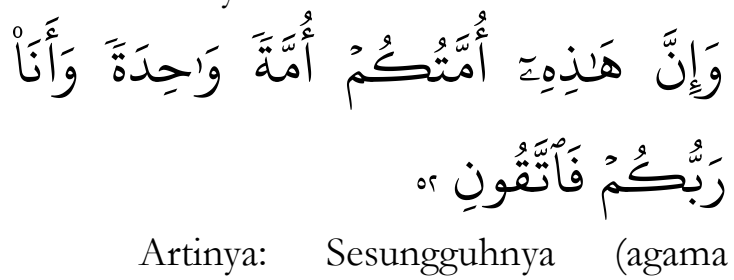
tauhid) ini, adalah agama kamu semua, agama yang satu, dan Aku adalah Tuhanmu, maka bertakwalah kepada-Ku

Serta dalam surah Al-Maidah ayat 8:



Artinya: Hai orang-orang yang beriman hendaklah kamu jadi orang-orang yang selalu menegakkan (kebenaran) karena Allah, menjadi saksi dengan adil. Dan janganlah sekali-kali kebencianmu terhadap sesuatu kaum, mendorong kamu untuk berlaku tidak adil. Berlaku adillah, karena adil itu lebih dekat kepada takwa. Dan bertakwalah kepada Allah, sesungguhnya 
Allah Maha Mengetahui apa yang kamu kerjakan

Serta Al-maidah ayat 48, surah Aljatsiyah 18, secara umum, pemikir Islam kebanyakan menggali konsep masyarakat madani dengan pendekatan kondisi masyarakat pada zaman Rasulullah, atau bahkan memberikan gambaran bahwa kepemimpinan Rasulullah sejalan dengan konsep masyarakat madani. Kondisi ini terjadi karena pemaknaan madani sendiri syarat dengan kata madinah.

Menurut Dr. Ahmad Hatta (Pasaribu, 2005) menjelaskan bahwa adanya konsep masyarakat madani tidak bisa dipisahkan pada masyarakat madinah, dan lebih menekan pada terjadinya piagam madinah. Piagam tersebut merupakan konsistitusi yang menjadi penegas hukum atas permasalahan yang terjadi antara umat Islam non Muslim. Piagam tersebut syarat dengan nilai-nilai HAM.

Sementara dalam presfektif Nurcholis Majid (Kosasih, 2000), masyarakat madani tidak memiliki korelasi yang kuat dengan istilah civil society, sebab keduanya memiliki akar sejarah yang berbeda-beda. Civil society syarat dengan sejarah kaum barat (Eropa), sedangkan masyarakat madani langsung berkorelasi dengan kehidupan di zaman rasulullah. Oleh sebab itu, presfektif ini coba dijelaskan dengan terang dengan Nurcholish Majid agar tidak cepat menghubungkan keduanya (Adi Suryadi, 1999).

Terlepas dari pemaknaan tersebut, sebagian pemikir menganggap bahwa konsep masyarakat madani sudah dicetuskan sejak zaman Cicero (104-43SM) dengan menggunakan istilah civil society Fitria dan Sutrisnowati (2013). Dalam filsafat Cicero istilah civil society dihubungkan dengan istilah the state (negara). Dengan artian, negara dijadikan sebagai komunitas yang mendominasi sejumlah komuntas lain tapi tetap dengan menggunakan sistem yang bertujuan untuk menegakkan keadilan dan kesejahtraan. Dari perbedaan tersebut terlihat ada semacam interpretasi yang berbeda dengan makna yang sama.

\section{Istilah Kepemimpinan Profetik}

Istilah kepemimpinan profetik
mengandung dua unsur kata "kepemimpinan" dan "profetik". Kedua unsur kata ini mengandung pengertian yang berbeda. Ditinjau dari aspek bahasa kepemimpinan dalam bahasa inggris disebut sebagai leadership. Leadership diambil dari kata leader yang berarti pimimpin to lead berarti kepemimpinan. Sedangkan secara deskripsi, kepemimpinan mempunyai makna dan penjelasan yang berbeda-beda.

Menurut pendapat Mukhtar Adullah dalam (Shohleh Subagja, 2010: 5) menyebutkan bahwa kepemimpinan merupakan "The ability to inspire people to make a total commitment to accomplishing organizational goals". Artinya kemampuan seseorang untuk bisa memberikan inspirasi supaya orang tersebut memiliki komitmen dalam mencapai tujuan organisasi.

Dalam sudut pandang lain, Robbins dalam (Sus Budiharto, 2015: 5) menyebutkan bahwa kepemimpinan memiliki berbagai macam defenisi, namun pada akhirnya bermuara pada kemampuan dan proses mempengaruhi orang lain untuk mencapai tujuan tertentu. Secara umum, kepemimpinan dimaknai sebagai cara ataupun metode yang digunakan oleh pemimpin untuk memberikan motivasi, masukan, dan kritikan pada orang yang dipimpinnya, dengan tujuan agar semuanya mau bersama-sama dalam mewujudkan visi dan misi pemimpin.

Sedangkan istilah "profetik" merujuk pada istilah kenabian. Kata profetik berasal dari kata "prophet" yang berarti nabi. Sedangkan dalam Oxford Dictionary "prophetic" adalah 1) "Of, pertaining or proper to a prophet or prophecy"; "having the character or function of a prophet"; (2) "Characterized by, containing, or of the nature of prophecy; predictive". Sehingga pengertian profetik identik dengan 
seseorang yang memiliki sifat atau ciri layaknya seorang nabi atau bisa orang diperkirakan dan diprediksikan memiliki sifat seperti seorang nabi.

Maka istilah kepemimpinan profetik merupakan gabungan dari dua defenisi yang bisa diartikan ke dalam beberapa terminologi. Pertama, kepemimpinan profetik mempunyai dimensi yang sama dengan kepemimpinan pada umumnya. Kepemimpinan di identikkan dengan kemampuan dalam mendorong dan memimpin anggota dalam mewujudkan visi bersama. Kedua, dimensi profetik menjadi poin penting, maka kepemimpinan harus di dasarkan pada sifat dan karakter seorang nabi, setidaknya bisa disamakan dengan upaya mewujudkan visi dan misi kenabian.

\section{Shiddiq}

Kriteria pertama ini harus ada pada diri pemimpin menurut Budiarto dan Himam (2006) adalah empat kompenen dasar sifat kenabian. Sidiq, yaitu kejujuran. Kejujuran merupakan bagian penting dalam konsep kepemimpinan profetik. Kejujuaran ini pun didasari oleh kebenaran hati nurani yang tidak pernah bisa dipungkiri oleh siapapun. Kriteria ini sudah termaktub dalam Surah Maryam ayat 50:

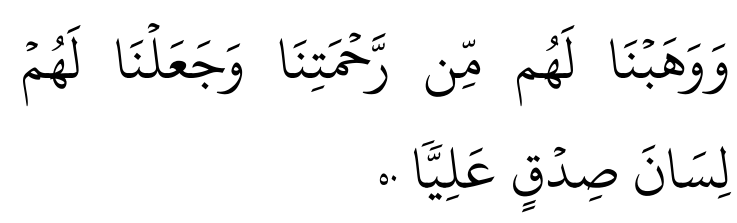

Artinya: Dan Kami anugerabkan kepada mereka sebagian dari rahmat Kami dan Kami jadikan mereka buah tutur yang baik lagi tinggi.

\section{Amanah}

Kriteria kedua adalah amanah. Amana merupakan kriteria yang harus melekat dalam diri pemimpin. Dalam bahasa sehari-hari amanah memiliki makna yang sama dengantanggungjawab. Hanya

saja, kriteria ini lebih dirasakan oleh orang yang dipimpin. Kriteria ini dijeaskan dalam Surah As-Syuaro ayat 106 dan 107:

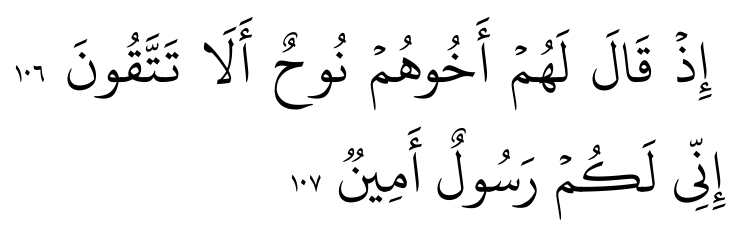

Artinya: Ketika saudara mereka (Nub) berkata kepada mereka: "Mengapa kamu tidak bertakwa. Sesunggubnya aku adalah seorang rasul kepercayaan (yang diutus) kepadamu.

\section{Tabligh}

Pemimpin harus memiliki komunikasi yang baik dengan orang yang dipimpinnya. Kemampuan dalam berkomunikasi ini disebut sebagai bagian dari tabligh. Seorang pemimpin hanya bisa menjalankan visi kenabiannya jika memiliki kemampuan menjalin hubungan yang baik dengan orang yang dipimpinnya. Hal ini difirankan Allah SWT dalam surah AlMaidah ayat 67:
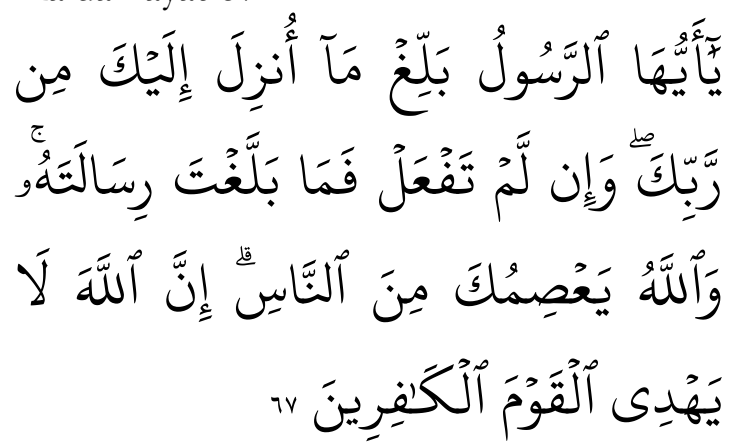

Artinya: Hai Rasul, sampaikanlah apa yang diturunkan kepadamu dari Tubanmu. Dan jïka tidak kamu kerjakan (apa yang diperintabkan itu, berarti) kamu tidak menyampaikan amanat-Nya. Allah memelibara kamu dari (gangguan) manusia. Sesunggubnya Allab tidak memberi petunjuk kepada orangorang yang kafir.

\section{Fathanah}


Fathonah yang bermakna cerdas, baik secara intelktual, emosional maupun spritual. Kecerdasan ini menjadi moda penting dalam menghadapi berbagai problematika dalam menjalankan kepempimpinan. Pada saat tertentu, pemimpin harus cepat dan tanggap dalam mengahadapi sisutai yang tidak diingin, serta harus mampu mengambil inisiatif yang tepat, agar kebijakan yang diputuskan tidak berbenturan dengan keinginan masyarakatnya.

Kretieria ini difirmankan oleh Allah dalam sura Al-An'am ayat 83:

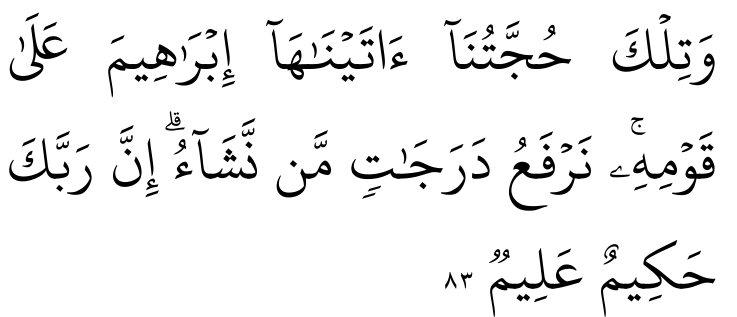

Artinya: Dan itulah bujjah Kami yang Kami berikan kepada Ibrabim untuk menghadapi kaumnya. Kami tinggikan siapa yang Kami kehendaki beberapa derajat. Sesunggubnya Tuhanmu Maba Bijaksana lagi Maba Mengetahui.

\section{Urgensi Kepemimpinan Profetik Dalam Mewujudkan Masyarakat Madani}

Kepemimpinan profetik mempunyai unsur penting dalam penataan masyarakat madani. Hal ini dikuatkan dengan pendapat Budiarto (2008) yang menyebutkan nilai dasar shiddiq, amanah, tabligh dan fathonah sebagai nilai mutlak dalam menjalankan kepemimpinan. Nilai tersebut secara nyata merupakan sifat utama dalam menjalankan kepemimpinan.

Lebih jauh nilai tersebut termanifestakan dalam kepemimpinan profetik yang diutarakan oleh Kuntowijoyo (1992) yang manafsirkan kepemimpinan diarahkan pada upaya perwujudan surah Ali Imran ayat 110 . Ayat tersebut mengandung nilai humanisasi, liberasi dan transendensi. Ketiganya memiliki unsur yang sangat tepat dalam perwujudan masyarakat madani.
Hanya saja, kepemimpinan profetik yang hendak dibangun belum sepenuhnya menjadi rujukan utama. Kepemimpinan profetik dianggap terlalu menjadikan unsur ketuhanan sebagai unsur utama. Padahal konsep ini sebenarnya belum diterima secara luas, terutama bagi mereka yang memang bukan beragama Islam atau bahkan belum beragama sama sekali.

Tuntutan dasar dari kepemimpinan profetik adalah penjalanan roda pemerintahan sesuai dengan sifat kenabian. Dalam pengertian lain, Muhammad sebagai pemimpin telah menjadikan nilai-nilai yang baik yang seharusnya menjadi model ideal. Padahal dalam kehidupan nyata, banyak pemikir politik menilai kepemimpinan bukan pada tataran nilai dan moral. Lebih mengutamakan kepentingan politik dibanding kepentingan lainnya.

Menilik hal tersebut, maka sebenarnya terasa sulit untuk diimpelementasikan. Masyarakat non Muslim juga masih melihat adanya dikotomi kepemimpinan profetik antara Muslim dan non Muslim. Mereka juga melihat bahwa kepemimpinan profetik hanya bisa dilakukan oleh manusia yang taraf kemanusiaanya berbaur dengan kenabian.

Di negara Muslim sendiri, urgensi kepemimpinan profetik juga tidak bisa dijadikan sebagai model. Antara ras Arab dan non Arab juga berbenturan kepentingan. Sehingga terasa makin sulit untuk diimpelementasikan dalam kehidupan bermasyarakat, berbangsa dan bernegara.

Hanya saja perlu digaris bawahi, bahwa Muhammad sebagai nabi dan rasul yang mengimplentasikan nilai profetik bukanlah berada dalam ruang yang hampa. Model kepemimpinan yang dicetuskan merupakan rumusan nyata terhadap perwujudan dari masyarakat madani itu sendiri. Pada masa Muhammad konsep masyarakat madani ini terwujud. Sehingga tidak mungkin keberadaan sebuah sistem yang dijalankan oleh nabi Muhammad hanya ditujukan di zamannya saja. 
Dalam konteks ini penulis sependapat dengan tulisan yang dibuat oleh Budiarto (2015) "Peran Kepemimpinan Profetile Dalam Kepemimpinan Nasional', yang secara nyata menjadikan konsep kepemimpinan nabi sebagai rujukan utama dalam mewujudkan sistem kepemimpinan nasional. Dengan tulisan ini Budiarto tetap pada pendiriannya, untuk menjadikan kepemimpinan profetik sebagai jawaban terhadap berbagai permasalahan yang dialami oleh negara-negara Muslim.

Secara internal, terutama bagi bangsa Indonesia. Model kepemimpinan profetik belum dijadikan sebagai rujukan utama. Nilai dan moral yang dijadikan masih terbatas pada kata-kata yang tekstual. Konten yang belum tentu menjadikan nilai kepempinan rasulullah sebagai rujukan. $\mathrm{Hal}$ ini terdapat diberbagai daerah di Indonesia sendiri.

Pada faktanya, berbagai masalah yang dihadapi oleh bangsa Indonesia sangat variatif. Terutama masalah $\mathrm{KKN}$ yang sampai saat ini belum mampu ditangani dengan cepat dan tepat. Disisi lain, moral dan etika pemimpin semakin jauh dari nilainilai yang ditanamkan oleh rasulullah. Terlebih lagi masalah ketimpangan sosial yang semakin menganga, hubungan ekonomi antara si kaya dan si miskin sudah tidak bisa dijalankan dengan nilai egalitaisnisme. Penegakan hukum juga semakin jauh dari ketetapan hukum itu sendiri. Masyarakat semakin skeptis dengan lembaga penegak hukukm. Hal ini tentu menjadi permasalahan yang harus ditangani dengan baik.

Keberadaan kepempinan profetik sebagai jawaban atas masalah tersebut belum dianggap urgen. Padahal keberadaan Indonseia yang sudah lebih dari 57 tahun perlu mendapatkan jawaban yang tepat. Model kepemimpinan saat ini belum mampu untuk menjawabnya. Masih banyak hal yang perlu dibenahi dan diperbaiki.

Dalam konteks ini penulis menemukan pendapat yang sama, seperti pada tulisan Prabowo Adi Widayat (203) tentang "Kepemimpinan Profetik: rekonstruksi Kepempimain berkarakter Keindonesiaan". Ada upaya nyata bahwa ada karakter keIndonesia pada kepemimpinan profetik. Nilai profetik masih aplicable dan acceptable pada masyarakat Indonesia.

Secara mendalam terlihat bahwa format kepemimpinan profetik dan konsep masyarakat madani memiliki persamaan dan kebutuhan dalam konteks Indonesia. Hal tersebut adalah:

\section{Kesesuaian Esensi}

Kepemimpinan profetik memiliki beberapa esensi mendasar. Dalam presfektif Budiarto (2008) konsep dasar dari kepemimpinan profetik sendiri merujuk pada sifat dasar nabi. Sifat dasar tersebut adalah Sidiq, Amanah, Tabligh dan Fathonah. Keempat sifat ini menjadi modal dasar nabi dalam menjalankan kepemimpinan.

Dalam prakteknya kepemimpinan ini dijalankan sesuai dengan harapan masyarakat di zaman itu. Masyarakat madinah menerima kepemimpinan nabi sebagai sebuah kepemimpinan ideal. Masalah dikotomi kesukuaan dapat diselesaikan oleh nabi. Sedangkan masalah ekonomi diperkuat dengan menjalankan beberapa bisnis pertanian. Dan yang paling penting, semuanya menerima kepemimpinan nabi.

Sifat dasar kepemimpinan tersebut juga merujuk pada ayat Ali Imran ayat 110 . Ayat ini menjelaskan tentang nilai-nilai yang harus diterapkan dalam kepemimpinan. Berangkat dari sifat humanisasi, dimana manusia yang satu harus mau menolong sesama. Manusia yang tidak hanya memikirkan dirinya sendiri, melainkan juga memikirkan orang lain. Setelah itu, kepemimpin diarahkan untuk melakukan liberasi atau pembebasan. Manusia harus dibebaskan dari kebodohan, kemiskinan dan ketidakadilan. Ketiganya merupakan 
sumber terjadinya penindasan dan ketidakteraturan dalam tatanan masyarakat.

Disisi lain, yang tidak kalah penting dari nilai tersebut adalah nilai transendensi. Manusia memiliki Tuhan yang memberikan kehidupan dan kelak akan dipertanggungjawabkan. Hal ini menjadi penting, sebab merasa diawasi secara nyata oleh manusia lain dapat memungkinkan terjadinya penyelewengan. Hanya saja, merasa diawasi oleh Tuhan membuat manusia semakin yakin untuk tetap berada pada kebenaran.

Sifat dasar nabi yang disebutkan oleh Budiarto dihubungkan dengan penafsiran ayat Ali Imran 110 salah satunya diwujudkan secara nyata dalam piagam madinah. Sebuah piagam yang mencerminkan kehidupan yang layak bagi masyarakat. Konflik yang selama ini terjalin antara kaum muslimin dengan non Muslim dapat teratasi. Piagam itu sendiri memuat sepuluh nilai penting (Maab dan Fauzan, 2012): (a) Kebebasan dalam melaksankan ajaran agama masing-masing. Dengan prinsip ini tidak ada lagi penindasan dengan mengatasnamakan agama sebagai basis dalam penenentangan tersebut; (b) Persaudaraan seagama dan kehausan untuk menanamkan sifat solitaritas yang tinggi sesama manusia. Nilai ini dijalankan dengan memberikan kesempatan yang sama untuk menjalankan ibadahnya masing-masing; (c) Mejadikan persatuan politik sebagai upaya yang sama dalam mewujudkan keadilan dan ketentraman sesama. Dengan pengertian bahwa masyarakat Mekkah dan Madinah harus hidup bersama pasca 10 tahun perjanjian; (c) Setiap anggota masyarakat mempunyai kedudukan yang sama tanpa adanya pembedaan terhadap warna kulit dan kesukuan; (d) Setiap manusia mempunyai hak yang sama dalam mendapatkan keadilan dan ketentraman dalam menjalankan keyakinannya sebagai sebuah hak dasar; (e) Kedudukan yang sama dimata hukum diterapkan, setiap manusia yang memiliki nyawa maka selama itu pula persamaan hak dimata hukum harus disamakan; (f) Penegakan hukum pada pelanggaran terhadap perjanjian yang sudah disepakati bersama. Dengan membuat perjanjian maka selama itu pula kedua belah kubu harus mentaatinya; (g) Memberlakukan hukum adat sebagai pedoman dalam menetapkan keadilan. Hukum adat yang dimaksud adalah hukum yang ada pada Mekkah dan Madinah itu sendiri; (h) Perdamaian dengan perundingan mengisyarakatkan bahwa setiap konflik dapat diselesaikan dengan mengedepankan nilai-nilai persamaan dimata hokum; dan (i) Pemberian kebebasan dalam memilih dan menjalankan agama sesuai dengan keyakinan yang sudah dijalani.

Dengan adanya piagam madinah tersebut mengindikasikan bahwa adanya persamaan hak sebagai individu yang hidup di negara masing-masing. Hidup rukun dibawah pilar HAM yang sudah melekat pada diri masing-masing. Tujuannya adalah terciptanya kedamaian dan keadilan yang selama ini sulit untuk didapatkan. Lebih jauh juga dinilai oleh (Ahmad Sukardja, 1995) sebagai dasar kehidupan rukun dalam membentuk persatuan dan kesatuan.

Berdasarkan pada model dari kepemimpinan profetik maka ditemukan beberapa unsur kesamaan yang membuat kepemimpinan profetik yang mampu dalam mewujudkan masyarakat madani. Masyarakat yang tercipta sebagai manifestasi dari keberadaan kehidupan yang syarat dengan nilai-nilai agama. Unsur kesamaan tersebut adalah: (a) Secara konseptual istilah profetik menjadikan nabi Muhammad sebagai referensi utama. Baik secara konsep maupun dalam konteks implementasi. Dan masyarakat yang ada pada zaman tersebut disebut oleh sebagian dari pemikir sebagai manifestasi nyata dari masyarakat madani. Sederhananya, kedua konsep ini lahir di zaman yang sama dan diimpelentasikan oleh pemimpin yang sama dan diterima oleh masyarakat yang sebagai bentuk nyata sebuah masyarakat yang ideal. Dianugerahi berbagai potensi sosial, ekonomi politik yang kondusif; (b) Dalam konteks nilai yang 
diperjuangkan maka terlihat bahwa nilai humanisasi, liberasi dan transendensi syarat dengan nilai yang melekat pada penegakan HAM. Manusia tidak hanya berada pada ranah individual namun juga berada pada ranah masyarakat. Keduanya memiliki peran sentral yang saling berkait satu dengan yang lainnya. Nilai humanisasi misalkan yang penuh dengan proses terjadinya pemanusiaan dari manusia yang satu kemanusia yang lain; (c) Istilah masyarakat madani dianggap lebih mengedepankan peran sentral agama dalam mewujudkan masyarakat yang ideal. Dalam artian, pemimpin dan masyarakat terdorong untuk menciptakan masyarakat ideal yang mengandung unsur ketuhanan. Unsur ini yang sulit tercapai pada konsep civil society. Jika konsep civil society cenderung lepas dari nilai ketuhanan, maka masyarakat madani secara implementatif harus menjadikan nilai ketuhanan sebagai nilai utama; (d) Pemenuhan kebutuhan dasar manusia dalam menjalankan aktivitasnya tertuang dalam kedua konsep tersebut. Manusia bukan sebagai objek politik, melainkan sebagai entitas yang harus mendapatkan perlindungan. Terutama dalam pemenuhan kebutuhan dasar sebagai manusia yang tidak bisa ditawar dengan apapun; (e) Idealnya, kepemimpinan profetik berada pada level elit, meskipun elit tidak bersifat elitis pada masyarakat. Tidak menggunakan kekuasaan sebagai nilai prestesius untuk melakukan tekanan pada masyarakat. Sedangkan masyarakat madani, meskipin juga menganut kepemimpinan demokratis, pada faktanya masyarakat madani lebih diarahkan pada kondisi masyarakat yang harus dijalankan oleh pemimpin. Kedua hal ini memiliki hubungan yang saling berkaitan, tidak bisa dipisahkan. Akan sulit menciptakan masyarakat madani tanpa kepemimpinan profetik.

Dari kelima hal tersebut terlihat bahwa konsep kepimpinnan profetik berada pada tataran implementatif seorang penguasa. Sedangkan masyarakat madani berada pada kondisi sosial masyarakat yang harus tercipta. Masyarakat madani diarahkan pada cita-cita bersama dimana masyarakat dan pemimpin mendapatkan jatah yang sama untuk mewujudkan masyarakat sesuai dengan yang diekspektasikan oleh semua pihak.

\section{Solusi Kepemimpinan Nasional}

Pada faktanya kondisi

kepemimpinan hari ini berada diluar ekspektasi semua pihak, terutama dikalangan umat Islam. Negara-negara dengan umat Islam mayoritas seperti terhambat regenerasi kepemimpinannya. Terhadap oleh arogansi politik yang terus menerus terjadi. Sehingga perseteruan antara negara Muslim yang satu dengan negara muslim yang lain sangat sulit dihindari. Disebabkan oleh kepentingan politik dan ekonomi. Politik dan ekonomi yang tidak sejalan dengan apa yang diharapkan oleh rasulullah.

Secara ke-Indonesiaan, urgensi penerapan kepemimpinan profetik disebabkan oleh beberapa fakta ketidaksesuaian keadaan masyarakat saat ini dengan prinsip dasar dari masyarakat madani itu sendiri. Beberapa diantaranya tercermin dari beberapa hal berikut:

(a) Korupsi, Kolusi dan Nepotisme. Bangsa Indonesia merupakan salah satu bangsa yang kaya raya akan sumber daya alam dan sumber daya manusia. Kedua hal ini belum termanfaatkan dengan baik, salah satunya disebabakan oleh praktek KKN yang sudah menggurita. Dari tingkatan elit sampai tingkatan RT juga terjadi; (b) Data dari Peter Carey dalam (Tempo, 2016) menunjukkan dari tahun 2001 sampai pada tahun 2015 Indonesia telah mengalami kerugian sebesar Rp. 205 Trilun. Hal ini setara dengan hilangnya pembangunan jalan tol sepanjang $871 \mathrm{~km}$. Sebuah kondisi diluar ekspektasi masyarakat; (c) Tergerusnya moral dan etika Pemimpin; dan (d) Arogansi politik para pemegang kekuasaan seringkali tidak memberikan contoh dan teladan yang ideal. Pertentangan politik 
seringkali berujung pada kata-kata yang tidak pantas untuk disampaikan pada publik. Publik dipertontonkan dengan berbagai pertentangan antar elit partai yang mengakibatkan kondisi politik tidak berjalan kondusif.

Dalam tulisan Nugroho (2013) dinyatakan bahwa ada beberapa kasus diluar nalar sosial masyarakat yang terjadi pada pemimpin. Seorang ketua partai yang katanya bersih dan islami harus dibawa oleh KPK dan juga nikah siri dengan beberapa orang. DiImpeachment-nya beberapa rang karena kasus menikahi anak dibawah umur. Dan juga etika pada publik yang mengindikasikan sikap dan sifat arogan. Akibat dari kondisi ini masyarakat tidak melihat arah good governance dan clean goverment. Bahkan kepercayaan masyarakat pada pemerintah semakin hari semakin berkurang.

(a) Ketimpangan social. Masalah ini semakin pelik ketika ada penelitian yang menyebutkan bahwa empat orang Indonesia menguasai 100 juta pendapatan warga Indonesia. Artinya persebaran akses ekonomi masih menjadi milik segelintir orang di negeri ini. Dalam data yang dikeluarkan oleh Kementrian PPN/Bappenas (2013) dinyatakan jumlah kemiskinan di Indonesia sebesar 11, $25 \%$. Jumlah ini ternyata memberikan dampak pada GINI rasio sebesar 0, 413. Dilihat dari data tersebut maka Indonesia berada pada urutan ke 6 sebagai negara dengan indeks GINI tertinggi. Sehingga terlihat jelas bahwa sumber ekonomi masih dikelola dan dimiliki oleh segelintir orang saja.

(b) Demokrasi transaksional. Sistem demokrasi memang telah diterapkan di negera ini. Namun pada kenyataannya sistem demokrasi yang diusung sangat transaksional. Visi dan misi kepemimpinan tidak memberikan arti penting, sebab basis modal yang paling menentukan. Hal ini terbukti dari menguatnya suap menyuap di strukutur pemerintahan. Hal ini juga terjadi pada pengurusan beberapa administrasi yang dilakukan oleh masyarakat. Seperti pengurusan e-KTP dan SIM. Mahfud MD (2013) memberikan slogan dengan "Demokrasi di Indonesia Sesat". Dibuktikan dengan adanya beberapa kepala daerah yang dianggap tidak punya kompetensi dan pengalaman dalam birokrasi dapat dengan mudah menang. Kemenangan ini sepenuhnya ditopang oleh kekuatan modal yang besar. Dengan demikian model demokrasi yang saat ini dijalankan telah membuat masyarakat seperti lupa yang diperdagangkan.

(c) Penegak dan Penegakan Hukum. Hikmah Juwono dalam (Sanyoto, 2008) bahwa penegakan hukum di Indonesia memiliki beberapa problem mendasar. Prolem terkait dengan uang mewarnai penegakan hukum. Hukum dijadikan komoditas politik yang mengakibatkan adanya diskriminasi dan syarat kepentingan. Disamping itu juga penegakan hukum seringkalia dipicu oleh pemberitaan media masa. Dengan kondisi yang ada, membuat penegakan hukum di Indonesia seakan makin jauh dari nilai-nilai hukum itu sendiri. Keadilan sebagai tujuan utama yang diinginkan oleh masyarakat sulit didapatkan. Aparat penegak hukum sepertinya tidak mengindahkan nilai hukum itu sendiri.

\section{KESIMPULAN}

Konsep masyarakat madani merupakan sebuah istilah yang merujuk pada masa kepemimpinan nabi Muhamammad. Di masa tersebut masyarakat hidup sesuai dengan tiga nilai dasar penting dalam masyarakat madani. Kehidupannya dipenuhi dengan penerapan nilai-nilai HAM. Antara pemeluk agama hidup berdampingan dengan sistem kehidupan ideal. Hal ini tercermin dari penetapan piagam madinah sebagai dimensi penting dalam tonggak kepemimpinan rasulullah.

Disamping itu juga, yang tidak kalah pentingnya adalah menjadikan penegakan keadilan sebagai instrument penting dalam masyarakat madani. Pada faktanya, hukum 
menjadi pilar penting dikarenkan posisinya sebagai solusi terhadap masalah antara warga yang satu dengan lainnya, bahkan dengan institiusi negera sekalipun.

Lebih jauh, pemenuhan kebutuhan pokok dan distribusi ekonomi juga diperlukan dalam membentuk masyarakat madani. Secara tidak langsung, kebutuhan sosial dan lingkungan tidak boleh mengenyampingkan kebutuhan jasmani. Kebutuhan sekunder yang bisa merubah tatanan sosial masyarakat, dikarenakan distribusinya yang tidak merata atau pembagiannya tidak sesuai dengan apa yang diharapkan.

Selain konsep dasar masyarakat madani, pemaknaan tersebut seringkali dipadankan dengan istilah civil society. Dalam pemaknaan ini, penulis menganggap bahwa istilah tersebut mempunyai konteks dan dimensi sejarah yang berbeda. Istilah civil society lebih merujuk pada kehidupan bangsa eropa, sedangkan masyarakat madani cenderung berada pada istilah Arab-Islam. Maka dalam hal ini, istilah masyarakat madani lebih tepat dimaksudkan sesuai dengan zaman rasulullah itu sendiri.

Masyarakat madani sendiri, hanya sebuah ilustrasi bagaimana seharusnya kondisi sosial masyarakat ideal. Sedangkan pilar penting dalam mewujudkan diserahkan pada masyarakat itu sendiri. Maka dalam kondisi zaman sekarang ini, Lembaga Swadaya Masyarakat dianggap sebagai kompenen penting. Disamping itu juga peranan Pers juga dibutuhkan, bahkan juga perguruan tinggi dan lembaga politik.

Konsep masyarakat madani sendiri, bukan sebuah kondisi yang muncul dengan sendirinya. Namun harus ditopang oleh sistem kepemimpinan yang kuat. Sistem kepemimpinan itu sendiri adalah kepemimpinan profetik. Dianggap sangat penting dikarenakan masyarakat madani dengan kepemimpinan profetik mempunya esensi yang sama.

Impelementasi masyarakat madani terjadi pada masa rasulullah maka konsep kepemimpinannya juga harus merujuk pada masa rasulullah itu sendiri. Dalam pelaksanaanya, masyarakat madani hanya akan terwujud jika pemimpin memiliki nilainilai yang patut dijadikan sebagai rujukan dan panutan. Nilai-nilai itu sendiri adalah, Shidiq, Amanah, Tabligh dan Fathonah.

Dalam ranah lain, keempat nilai tersebut dihubungkan langsung dengan kepemimpinan yang mempunyai tujuan untuk humanisasi. Memanusiakan manusia sesuai dengan kodratnya. Melakukan pembebasan atau liberasi dengan menuntaskan masalah kebodohan dan kemiskinan. Sedangkan transendensi merupakan dimensi yang kuat untuk menjadikan kepemimpinan tidak hanya bersifat duniawi tapi juga ukhrowi. Manusia berada pada tahapan yang tidak hanya berorentasi pada materi semata.

Urgensi dalam kontesk lain terlihat dari kondisi sosial masyarakat Indonesia saat ini. Masih berkutat pada permasalahan Korupsi, kolusi dan nepotisme yang sulit untuk diberantas. Masalah ketimpangan sosial yang belum dapat diselesai dengan baik. Penegak dan penegakan hukum yang tidak sesuai dengan harapan. Dan ditambah lagi sistem demokrasi yang sangat transaksioanl. Tidak memberikan ruang yang cukup bagi generasi muda untuk tetap tumbuh dan bergerak dengan nyata.

\section{DAFTAR PUSTAKA}

Astridya Paramita Dan Lusi Kristiana. 2013. Teknik Focus Group Discussion Dalam Penelitian Kualitatif (Focus Group Discussion Tehnique In Qualitative Research. ) Buletin Penelitian Sistem Kesehatan - Vol. 16 No. 2 April 2013: 117-127

Azra, Azyumardi. (2004). Menuju Masyarakat Madani. Bandung: Remaja Rosdakarya

Babbie, Earl. (2010). The Basics of Social Research. United States: Wadsworth.

Budiharto, Sus dan Fathul Himam. Konstruk. Teoritis dan Pengukuran Kepemimpinan 
Profetik. Jurnal Psikologi Volume 33, No. 2.

Budiharto, Sus. (2015), Peran Kepemimpinan Profetik dalam Kepemimpinan Nasional. Inter-Islamic Conference on Psychology, At Yogyakarta, Volume: 1.

Budiharto, Sus. 2015. Peran Kepemimpinan Profetik Dalam Kepemimpinan Nasional. Seminar Nasional The 1st National Conference on Islamic Psychology dan InterIslamic Conference on Psychology di Yogyakarta.

Febriyani, Azizah. (2007), Konsep Masyarakat Madani Dalam Presfektif PKS, Skripsi UIN Syarif Hidaytullah.

Fitria, Vita dan Sutrisnowati. (2013), Civil Society, Konsep Ummah Dan Masyarakat Madani, Humanika; Kajian Ilmiah Mata Kuliah Umum. Vol 13. No. 1

Ihsan, Muhammad. (2012), Hukum Islam Dan Moralitas Dalam Masyarakat Madani, Jurnal Al-Ahkam Volume 22.

Imron, Ali. (2013). Strategi Mewnjudkan Kepemimpinan Profetike Transformatif Melalui Pendidikan Demokrasi Menuju Civil Society. Seminar Nasional Dalam Rangka Dies Natalis ke-49 Universitas Negeri Yogyakarta.

Jainuri, Achmad. (2000) , Agama Dan Masyarakat Madani; Rujukan Khusus Tentang Sikap Budaya, Agama dan Politik, Jurnal Al-Afkar,Edisi III.

Kosasih, Aceng.(2000). Konsep Masyarakat Madani. diakses pada tanggal 3 Juni 2017 dari

File.upi.edu/Direktori/FPIPS/...AC ENG_KOSASIH/MASYARAKAT _MADANI.pd

Kuntowijoyo. (1991) . Paradigma Islam; Interpretasi untuk Aksi. Bandung: Mizan.

Maab, Husnul dan Fauzan. (2012), Konsep "Masyarakat Madani" sebagai Solusi Mewnjudkan Tata Pemerintahan yang Baik, Simposium Nasional Asosiasi Ilmuwan Administrasi Negara
(SIMNAS ASIAN) ke-2 di Universitas Slamet Riyadi, Surakarta.

Mustofa, Muhammad. (2000), Memahami Kerusuban Sosial, Suatu Kendala Menuju Masyarakat Madani, Jurnal Kriminologi Indonesia Vol. 1. No.1. Nugroho, Hibnu. (2013). Efektivitas Fungsi Koordinasi dan Supervisi Dalam Tindak. Pidana Korupsi Oleb Komisi Pemberatansan Korupsi, Jurnal Dinamika Hukum, Vol. 13 No. 3

Pasaribu, Rowland B. F. (2008). Masyarakat Madani. rowland_pasaribu.staff.gunadarma.a c.id/Downloads/.../bab-12masyarakat-madani.pdf.

Putra, Heddy Shri Ahimsa. (2011). Paradigma Profetik-Mungkinkah? Perlukah ?. makalah sarasehan UGM.

Sanyoto. (2008). Penegakan Hukum di Indonesia. Jurnal Dinamika Hukum Vol. 8 No. 3.

Soim, Muhammad. (2015), Miniatur Masyarakat Madani; Perspektif Pengembangan Masyarakat Islam, Jurnal RISALAH, Vol. 26 . No.1.

Subagja, Soleh (2010). Paradigma Nilai-Nilai Kepemimpinan Profetik; Spirit Implementasi Model Kepemimpinan Di Lembaga Pendidikan Islam, PROGRESIVA, Vol.3, no 1.

Sukardja, Ahmad. (1995) Piagam Madinah dan Undang-Undang Dasar 1945, Jakarta: UI Press.

Suroto. (2015), Konsep Masyarakat Madani Di Indonesia Dalam Masa Postmodern;Sebuab Analitis Kritis, Jurnal Pendidikan Kewarganegaraan: Volume 5. No.9.

Suryadi C, Adi. (1999) Masyarakat Madani; Pemikiran, Theory dan Relevansinya dengan Cita-Cita Demokrasi. Jakarta: Raja Grafindo.

Taufan, Andika Bima dan Budiharto. (2008), Proses Pengembangan Kepemimpinan Profetik. Naskah Publikasi Universitas Islam Yogyakarta. 
Tempo. (2016). Perang Jawa, Diponegoro, dan Sejarah Korupsi Indonesia, diakses pada tanggal 3 Juni 2017 dari https://nasional.tempo.co/read/70 8144/perang-jawa-diponegoro-dansejarah-korupsiindonesia\#LvyJBghb0ryZ8Bkj.99.

Widayat, Prabowo Adi. (2014). Kepemimpinan Profetik: Rekonstruksi Model Kepemimpinan Berkarakter Keindonesiaan. Jurnal Akademika Vol 19 no 1.

Yazid, Muhammad. (2010). Masyarakat Madani.

digilib.uinsby.ac.id/8316/2/Bab\%2 02.pdf. 